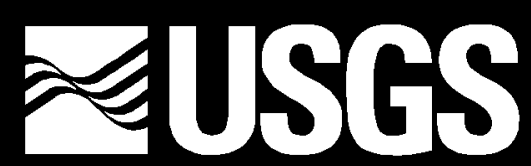

science for a changing world

\title{
Assessing the Potential for Future Reserve Growth in the Western Canadian Sedimentary Basin
}

By Mahendra K. Verma

Open-File Report 2005-1179

U.S. DEPARTMENT OF THE INTERIOR

U.S. GEOLOGICAL SURVEY 


\section{U.S. Department of the Interior \\ Gale A. Norton, Secretary}

\section{U.S. Geological Survey Charles G. Groat, Director}

\section{U.S. Geological Survey, Reston, Virginia 2005}

For product and ordering information:

World Wide Web: http://www.usgs.gov/pubprod

Telephone: 1-888-ASK-USGS

For more information on the USGS - the Federal source for science about the Earth, its natural and living resources, natural hazards, and the environment:

World Wide Web: http://www.usgs.gov

Telephone: 1-888-ASK-USGS

Although this report is in the public domain, permission must be secured from the individual copyright owners to reproduce any copyrighted material contained within this report.

Any use of trade, firm, or product names is for descriiptive purposes only and does not imply endorsment by the U.S. Government.

This report has not been reviewed for geologic nomenclature. 


\section{Preface}

This presentation - Assessing the Potential for Future Reserve Growth in the Western Canadian Sedimentary Basin - was prepared for a meeting of the Conference Board of Canada in Calgary, Canada, on May 24-25, 2005. The material is based on a paper entitled "Historical and Potential Reserve Growth in Oil and Gas Pools in Saskatchewan" by Mahendra K. Verma and Mitchell E. Henry. It was first presented at the $12^{\text {th }}$ Williston Basin Horizontal Well and Petroleum Conference, held in Minot, North Dakota on May 3-5, 2004, which was organized jointly by North Dakota Geological Survey and Saskatchewan Industry and Resources. The paper was published in Summary of Investigations, 2004, Volume 1, Miscellaneous Report 2004-4.1, by the Saskatchewan Geological Survey, Canada.

The topic of the presentation at the meeting in Calgary is the reserve growth in Western Canadian Sedimentary Basin (WCSB), which includes southwestern Manitoba, southern Saskatchewan, Alberta, northeastern British Columbia and the southwest corner of the Northwest Territories. Of the provinces within the WCSB, Alberta and Saskatchewan have most of the oil and gas accumulations. Therefore, the reserve growth study in these two provinces should capture the true reserve growth trend for the WCSB. At this time, only Saskatchewan has been evaluated for a detailed reserve growth study, and the results are being presented at the Calgary meeting. A similar study of Alberta is underway.

The presentation includes a definition of reserve growth, and the reasons for choosing Canada for reserve growth study. The objectives are to evaluate reserve growth at the pool and field levels, develop models for forecasting additional reserves from reserve growth, and determine reserve growth sensitivity to various parameters, such as pool size, oil gravity, and porosity. The presentation also includes a brief description of geology, reserve analysis (change in oil-in-place, oil reserves, gas-in-place, gas reserves, and recovery factors with time), reserve growth models for oil and gas, and a short-term forecast of additional reserves from reserve growth. 


\section{ZUSES}

science for a changing world

Assessing the Potential for Future

Reserve Growth in the Western

Canadian Sedimentary Basin

Mahendra K. Verma, Ph.D.

U.S. Geological Survey, Denver, Colorado

The Conference Board of Canada, Calgary, Alberta

May 24-25, 2005

U.S. Department of the Interior

U.S. Geological Survey 


\section{Reserve Growth}

* Reserve (or field) growth is defined as the increase in successive estimates of recoverable crude oil, natural gas, and gas liquids in discovered accumulations.

* Reserve-growth models contribute to realistic estimates of potential reserves of a field/ province/country.

* Because of different field development policies, reserve reporting systems, infrastructure, and levels of investment, each petroleum province around the world requires its own reserve growth model for a better estimate of potential reserves.

\section{ZUSGS}




\section{Western Canadian Sedimentary Basin (WCSB) and Reserve Growth}

* The WCSB covers an area of 1.4 million $\mathrm{km}^{2}$ of southwestern Manitoba, southern Saskatchewan, Alberta, northeastern British Columbia, and the southwest corner of the Northwest Territories.

* Of all the provinces in WCSB, Alberta and Saskatchewan have the most oil and gas reserves and resources.

* A reserve growth study has been completed for the Saskatchewan Province, and is described here. A similar study is ongoing for the Alberta Province.

\section{‡USGS}




\section{Why Canada's Reserve Growth Study?}

* Few known studies are available on reserve growth in Canadian oil and gas pools.

* Canada is strategically important to the United States for energy needs.

* Other considerations for selecting Saskatchewan first for this study:

- Generally well-kept, long historical records, and the opportunity to study reserve growth at both pool and field levels

- Smaller number of pools in Saskatchewan compared to Alberta

\section{¿USES}




\section{What is a pool and a field?}

Definitions by Canadian Gas Potential Committee (2001):

* Pool - a porous and permeable underground rock formation that contains a natural accumulation of crude oil or natural gas and related substances, or combination of them, that is confined by impermeable rock or water barrier, and that is individual and separate from other reservoirs.

* Field - a geographically defined area in which accumulations of crude oil, natural gas, and related substances occur. 


\section{Study Objectives for the Saskatchewan Province}

* Evaluate reserve growth both at the pool and field levels and develop models for forecasting additional potential reserves from reserve growth in Saskatchewan Province.

* Determine reserve growth sensitivity to various parameters, such as pool size, oil gravity, and porosity.

\section{‡USGS}




\section{Data}

Data includes estimates of oil-in-place/gas-in-place, and oil/gas reserves, as well as pertinent reservoir, production and geologic information.

* Source

- Saskatchewan Industry and Resources

* Length of records

- 1954 to 1984 hard copy

- 1985 to 2001 digital records

* Measurement units

- 1954 to 1977 Customary (American oilfield)

- 1978 to 2001 Metric 


\section{Methodology}

Two methods were employed to estimate reserve growth:

* Original method proposed by Arrington in early Modified

Arrington method -1960 s has been modified, and uses a slightly different approach to calculate cumulative growth factors, that requires summing recoverable pool/field reserves by year starting from the first production year of individual pools/fields.

* Group Growth method - It was first used for growth study in the oilfields in Volga-Ural and W. Siberia provinces. It requires a grouping of pools based on the length of records (11 years minimum in the $1^{\text {st }}$ group) followed by summing of recoverable reserves by year, before cumulative growth factors are calculated.

\section{ZUSGS}




\section{Geologic Setting}

The following two sedimentary basins contributed to hydrocarbon (HC) accumulations in Saskatchewan.

* Williston Basin - At least four total petroleum systems have contributed to HCs in the southeast part of the province.

- Three mature source rocks of Ordovician, Devonian, and Devonian to Mississippian age

- One immature source rock of Late Cretaceous age

* Alberta Basin - At least four thermally matured total petroleum systems within this basin have provided HCs in the southwestern and west-central parts of Saskatchewan.

- Source rocks include thermally mature Devonian to Mississippian shale, Jurassic shale, Upper Cretaceous shale, and possibly Lower Cretaceous shale and coal.

- Timing for peak generation in the Alberta Basin is reported to range from about 60 Ma for Devonian to about 25 Ma for Cretaceous rocks.

\section{\#USGS}




\section{Oil and Gas Pools and Production Areas, Saskatchewan Province}
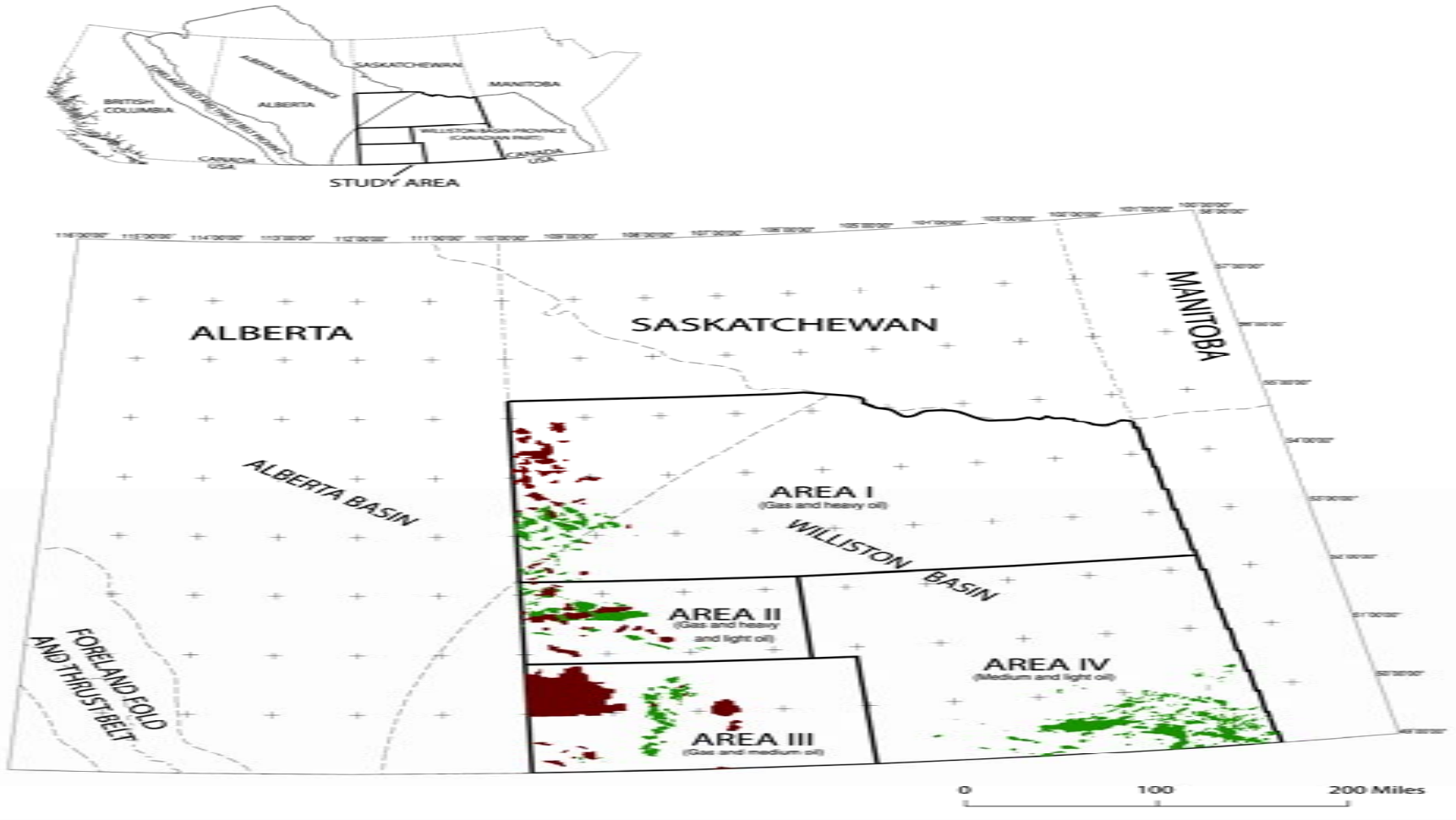


\section{Generalized Stratigraphic Chart for Southern Saskatchewan}

Source: Saskatchewan Industry and Resources 


\section{Distribution of Oil-In-Place and}

Reserves by Age of Reservoir Rocks in Saskatchewan Province

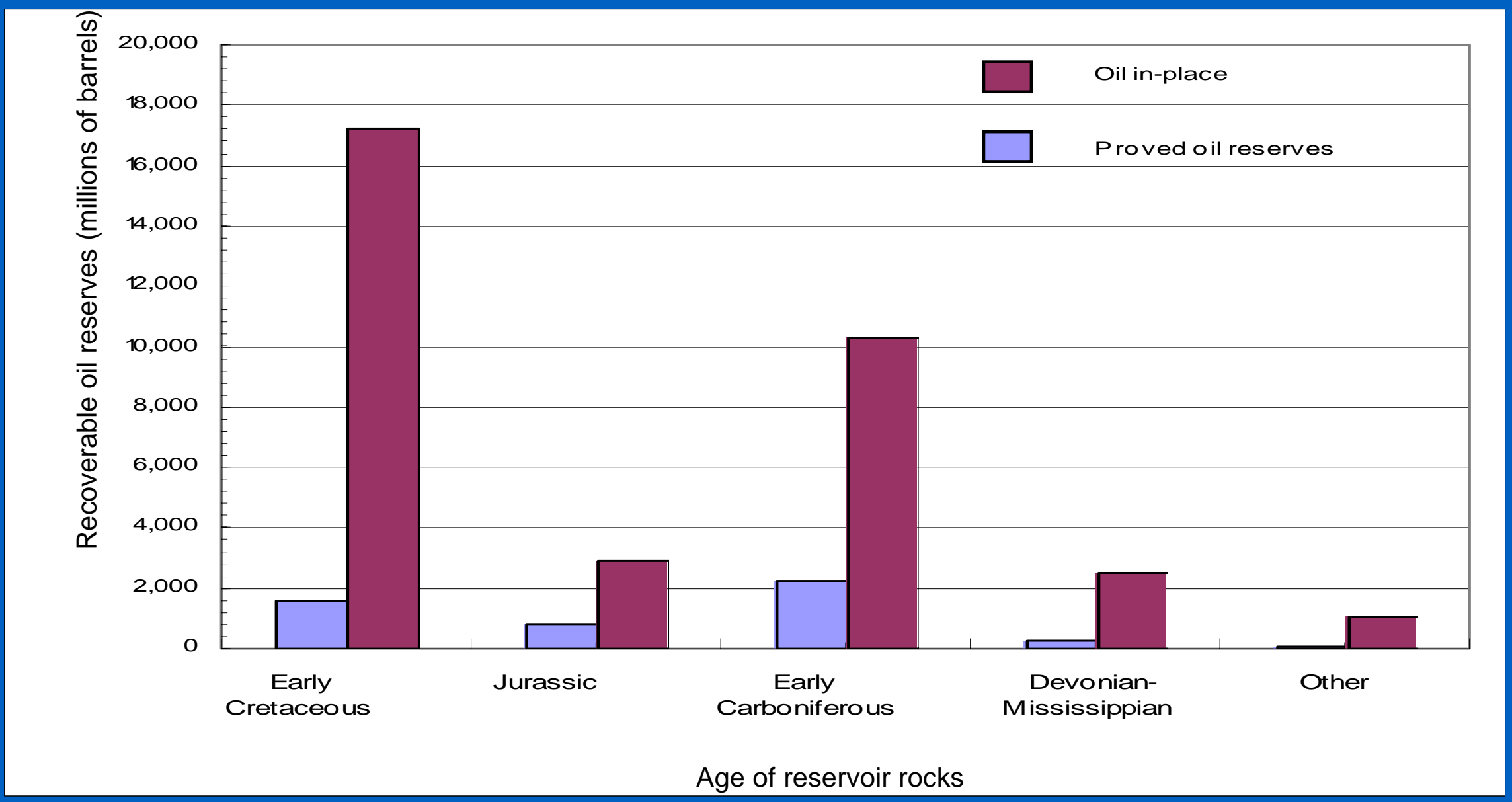

\section{ZUSGS}




\section{Oil-In-Place, Proved Oil Reserves and Recovery Factor}

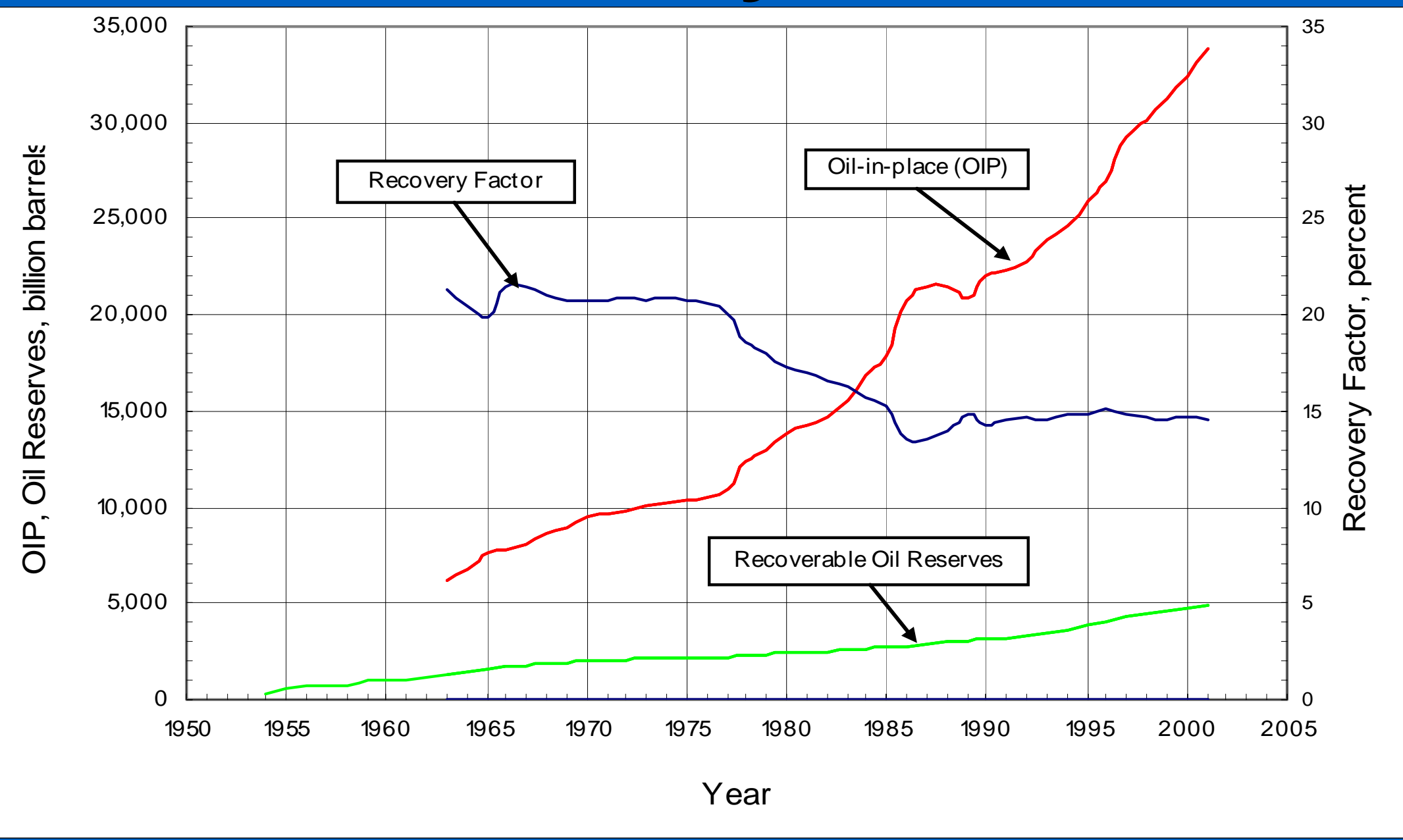




\section{Gas-In-Place, Proved Gas Reserves and Recovery Factor}

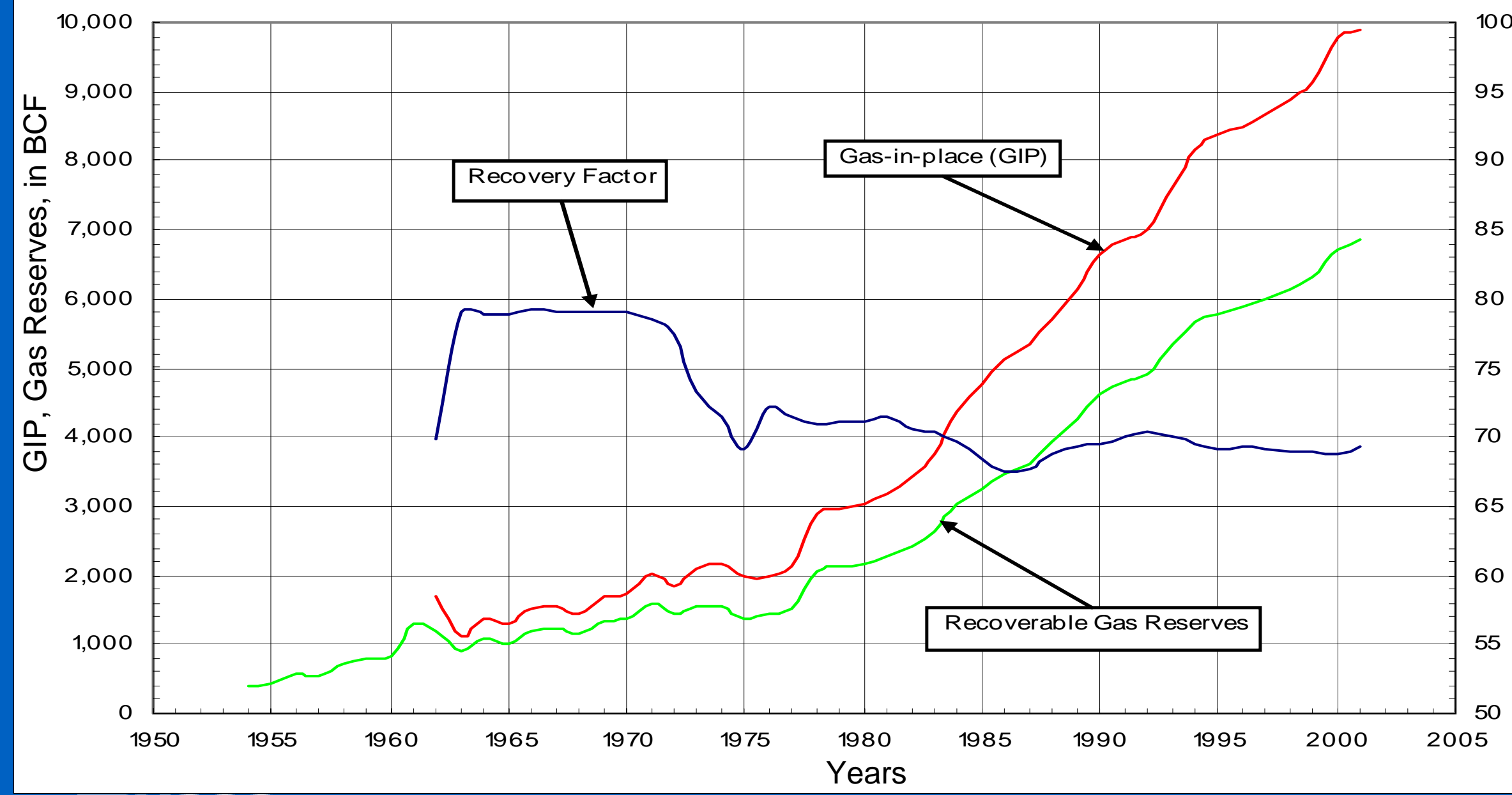




\section{Pool Selection Criteria}

Modified Arrington Method:

* All pools with reserve data through 2001

Group Growth Method:

\& Pools with at least 11 years of proved reserve data.

\& Recoverable reserve data must extend into 2001.

* Cumulative production at the end of 1st year is: -About half of what is reported at the end of 2 nd year. -Less than 10 percent depletion rate.

\section{\#USGS}




\section{Analysis Results}

\& 256 out of 648 oil pools and 51 out of 175 gas pools qualified for reserve growth analysis.

* These pools represent about 70 percent of oil and 62 percent of gas recoverable reserves of the entire province.

* Of the 51 gas pools, 45 are nonassociated and 6 are associated gas pools.

\section{\#USGS}




\section{Cumulative Growth Factor for Oil Pools}

Based on Modjified Arrington and Group Growth Methods

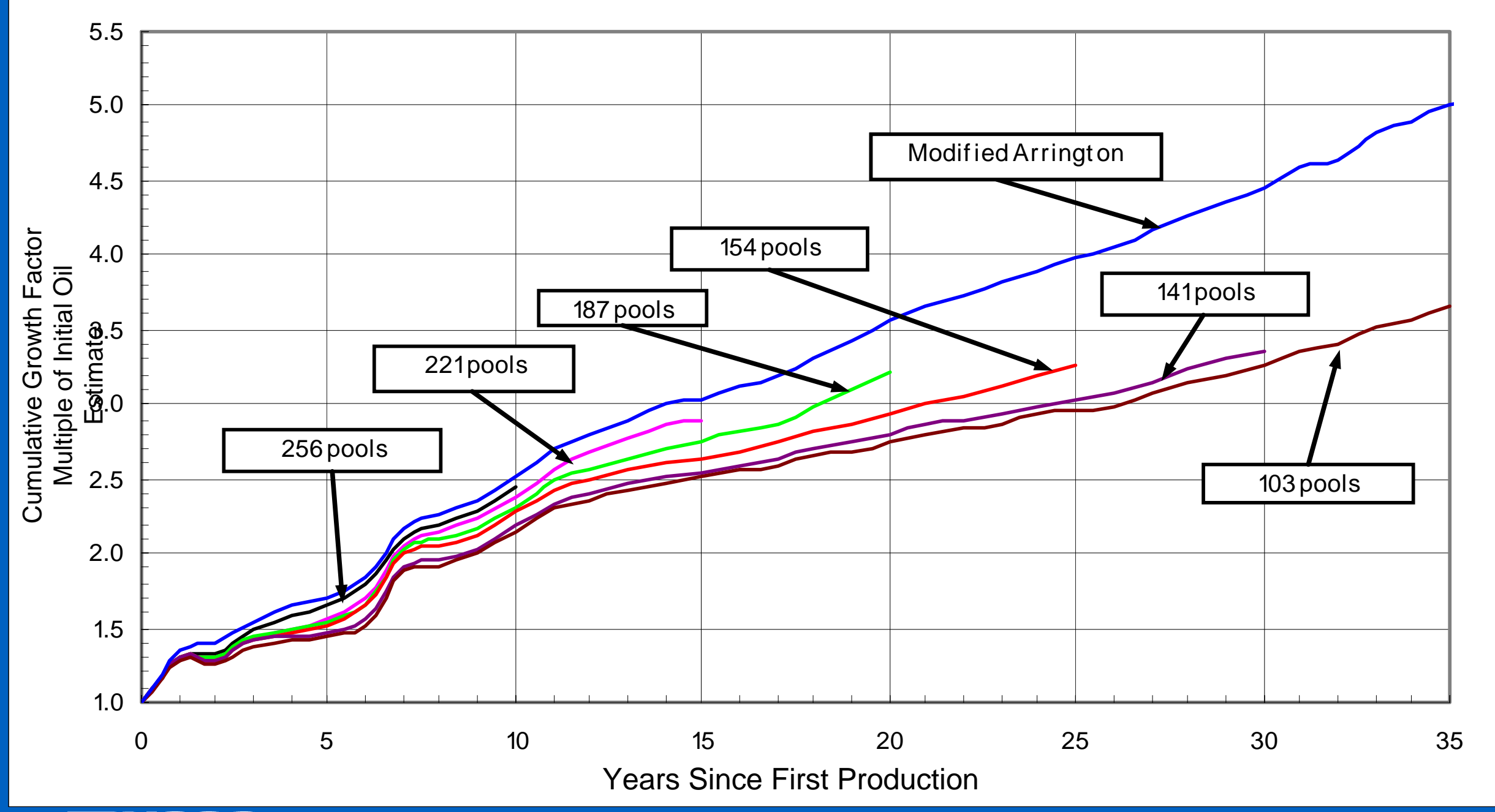

\section{ZOUSGS}




\section{Pool-size Distribution of 256 pools}

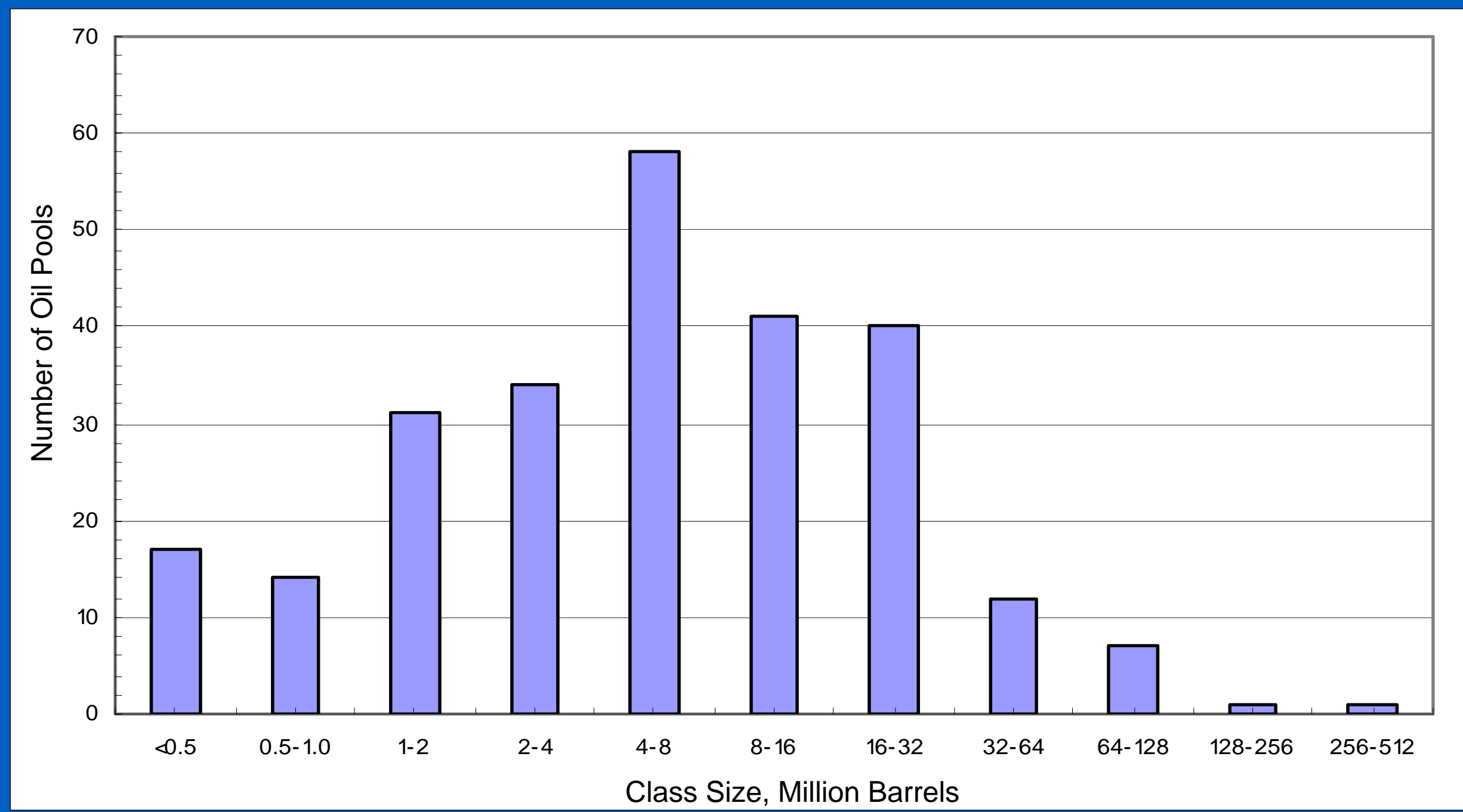

\section{ZUSGS}




\section{Cumulative Growth Factor: Oil Pools}

154 with 25 years growth; for pools with reserves $\leq$ or $>8$ MMBO

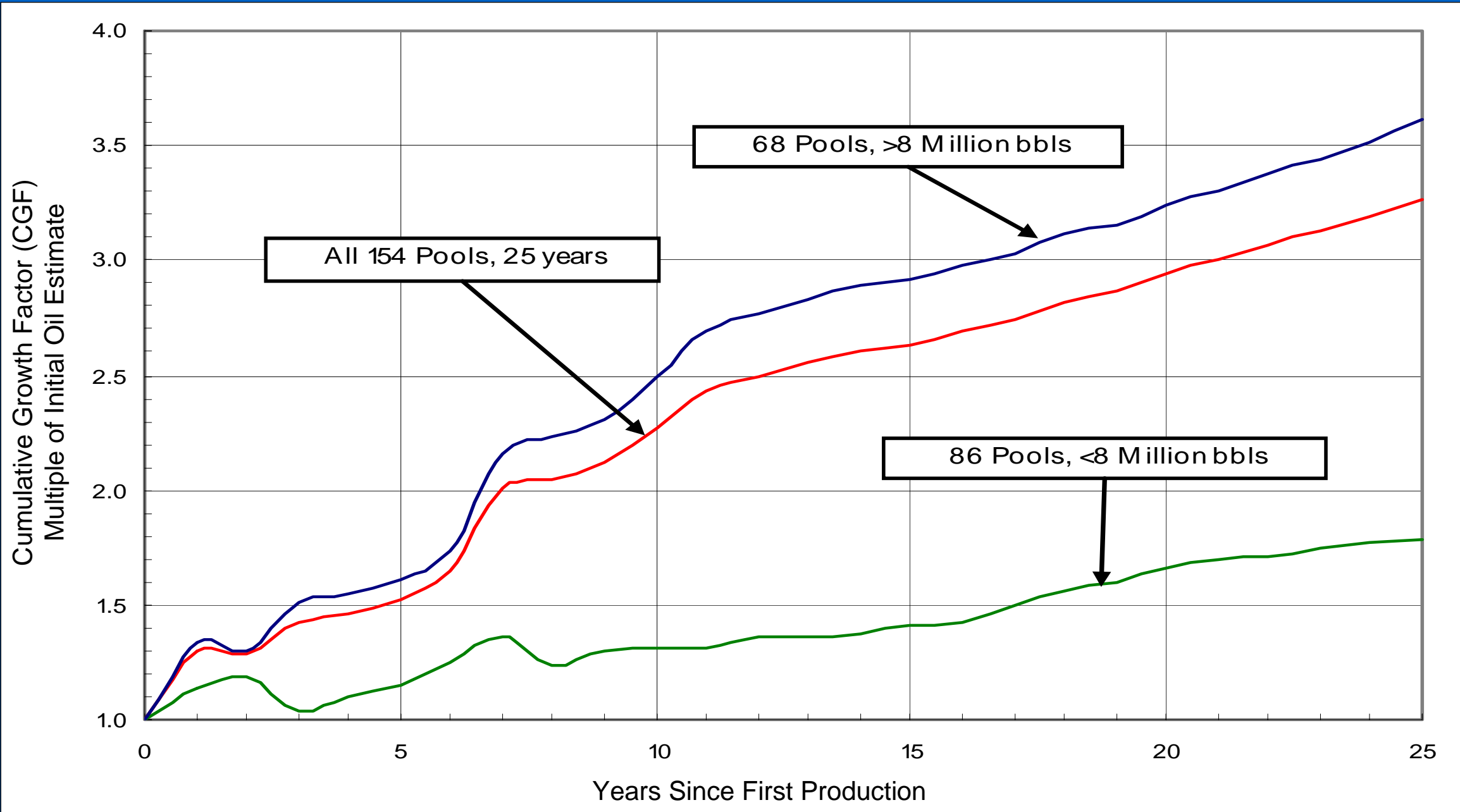




\section{Cumulative Growth Factor: OIl Pools}

154 with 25 years growth; for pools with reserves $\leq$ or $>100$ MMBO

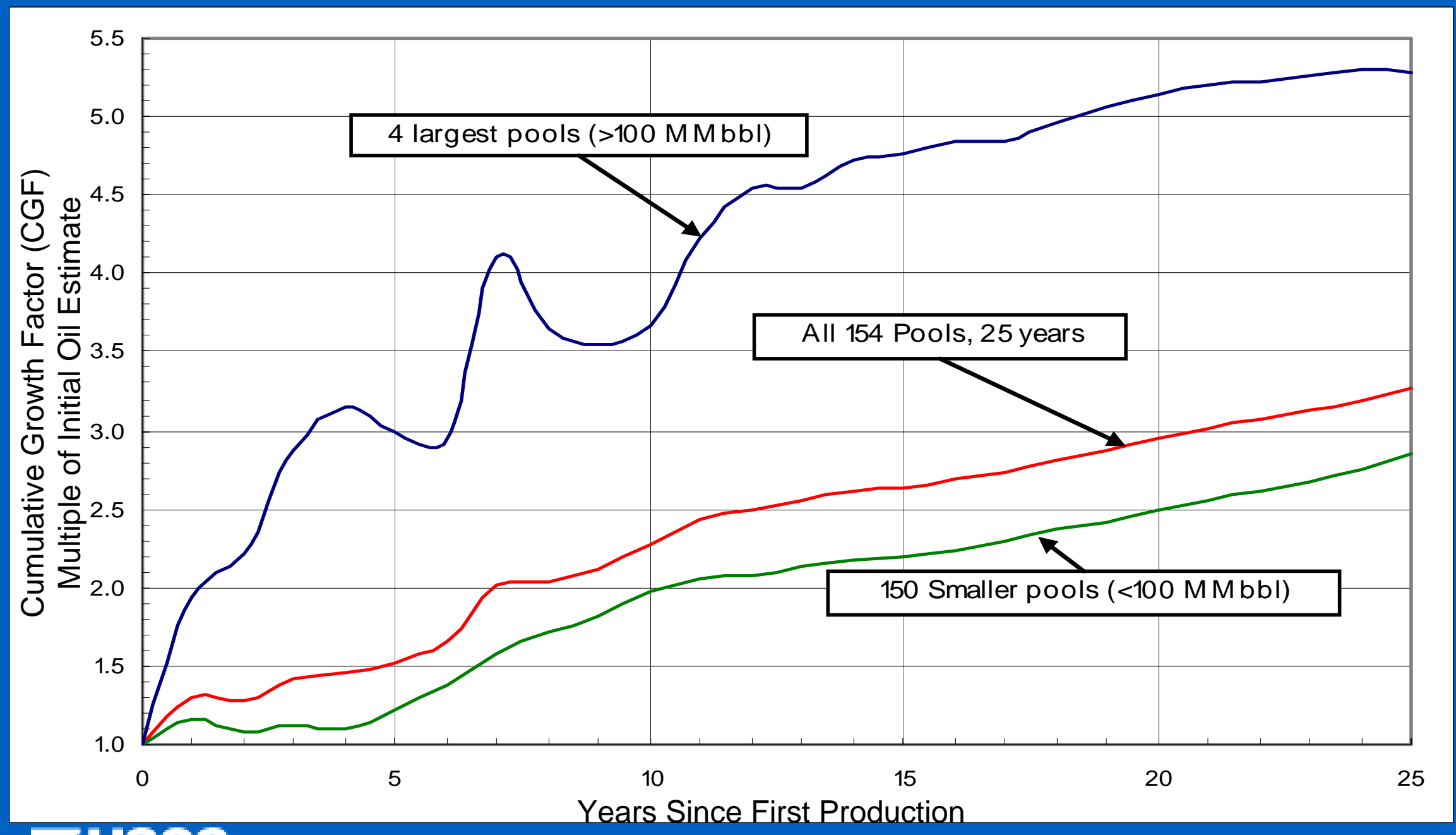

\section{ZOSES}




\section{Cumulative Growth Factor: OII Pools}

154 with 25 years growth; subsets based on oil gravity

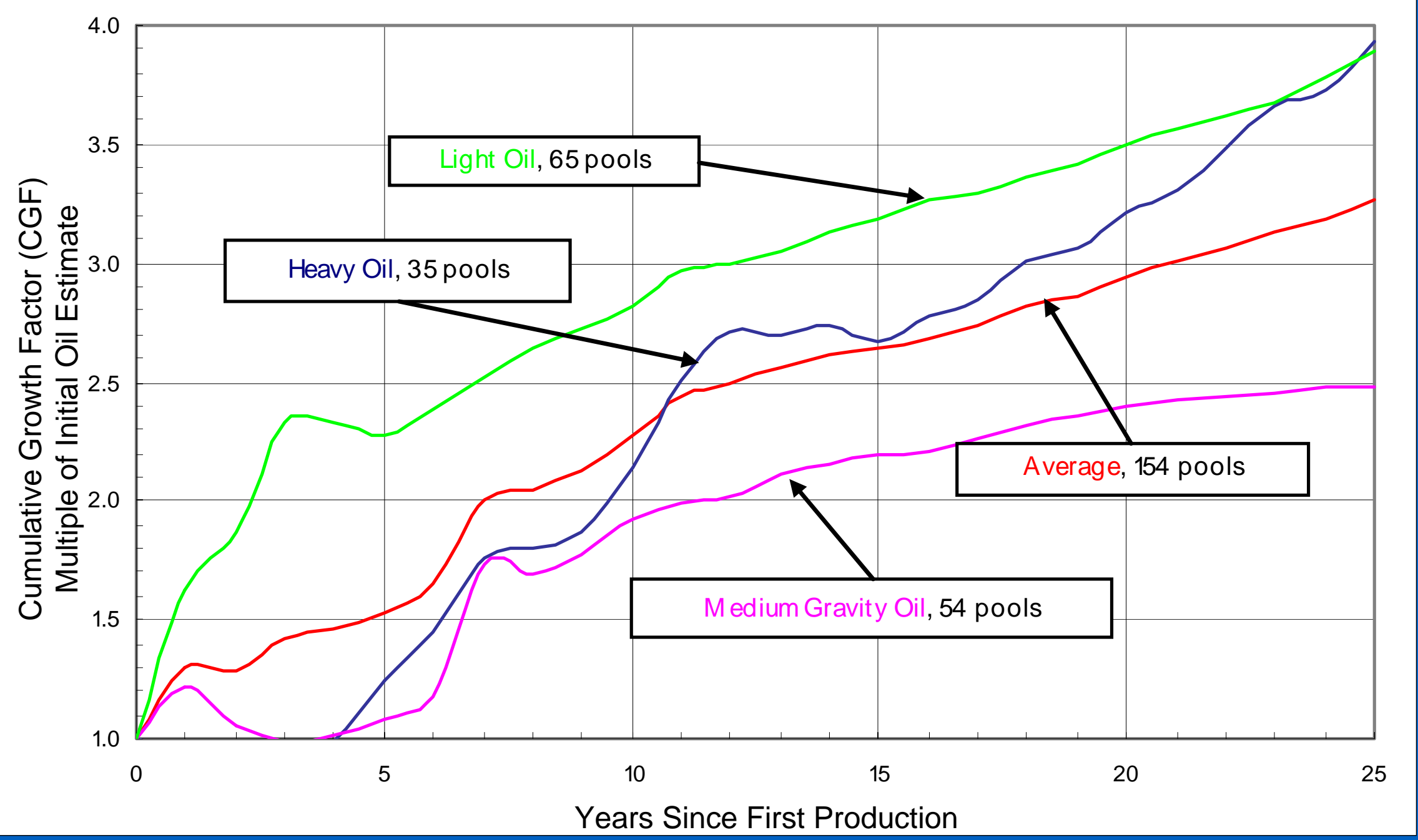

\section{ZUSGS}




\section{Cumulative Growth Factor: Oil Pools}

154 with 25 years growth; subsets based on porosity

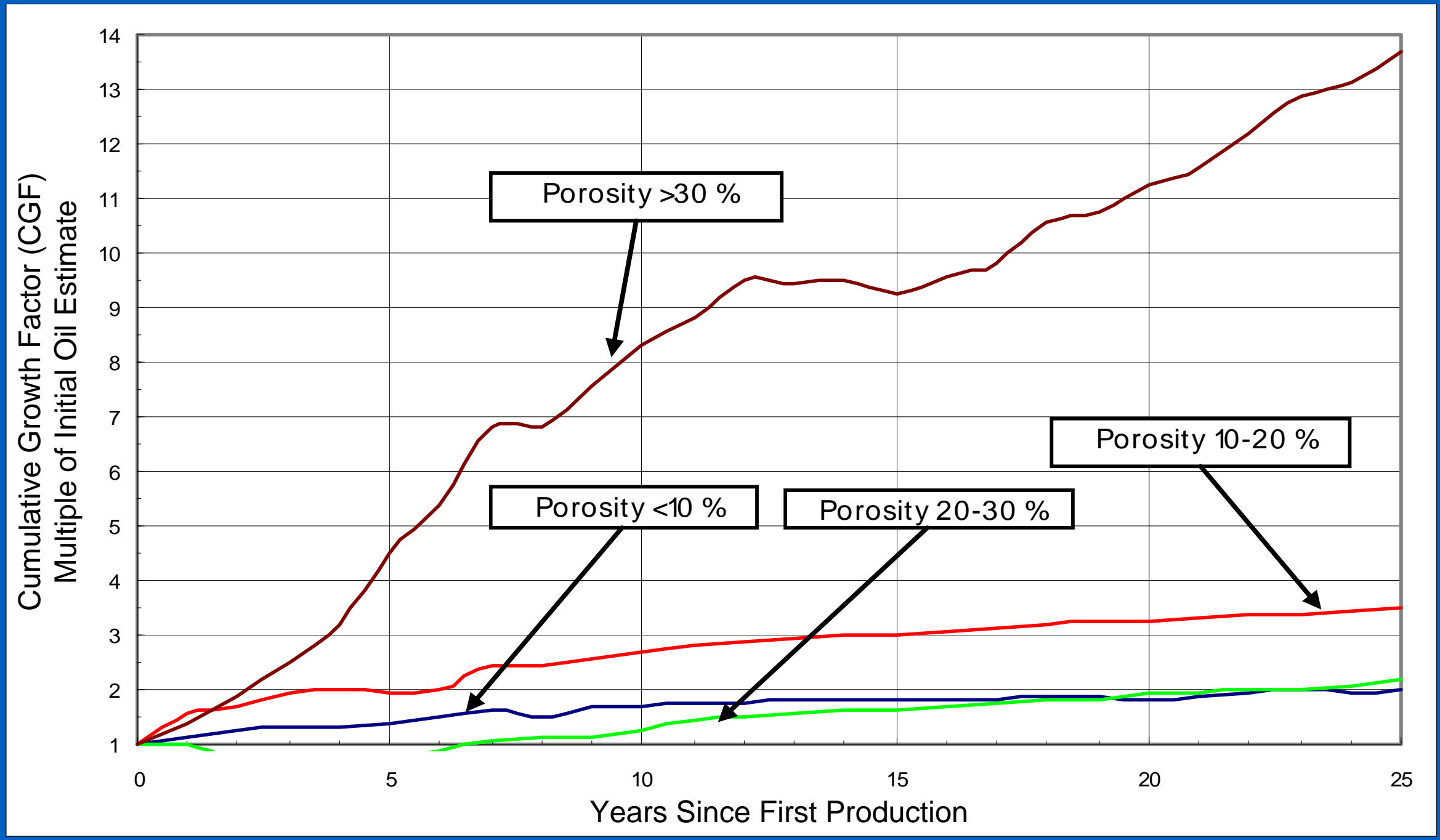

\section{ZUSGS}




\section{Reserve Growth at Pool and Field Levels}

* 256 oil pools, which have adequate data for reserve growth study, form 207 oil fields. Of the 207 fields, 42 contain two or more pools.

* The $\mathbf{4 2}$ multiple-pool fields contain a total of individual 91 pools (out of the total of 256 pools).

* Reserve growth for the group of 91 pools has been compared with the growth for the group of $\mathbf{4 2}$ fields.

\section{ZUSGS}




\section{Cumulative Growth Factor for Oil Reserve growth at field level}

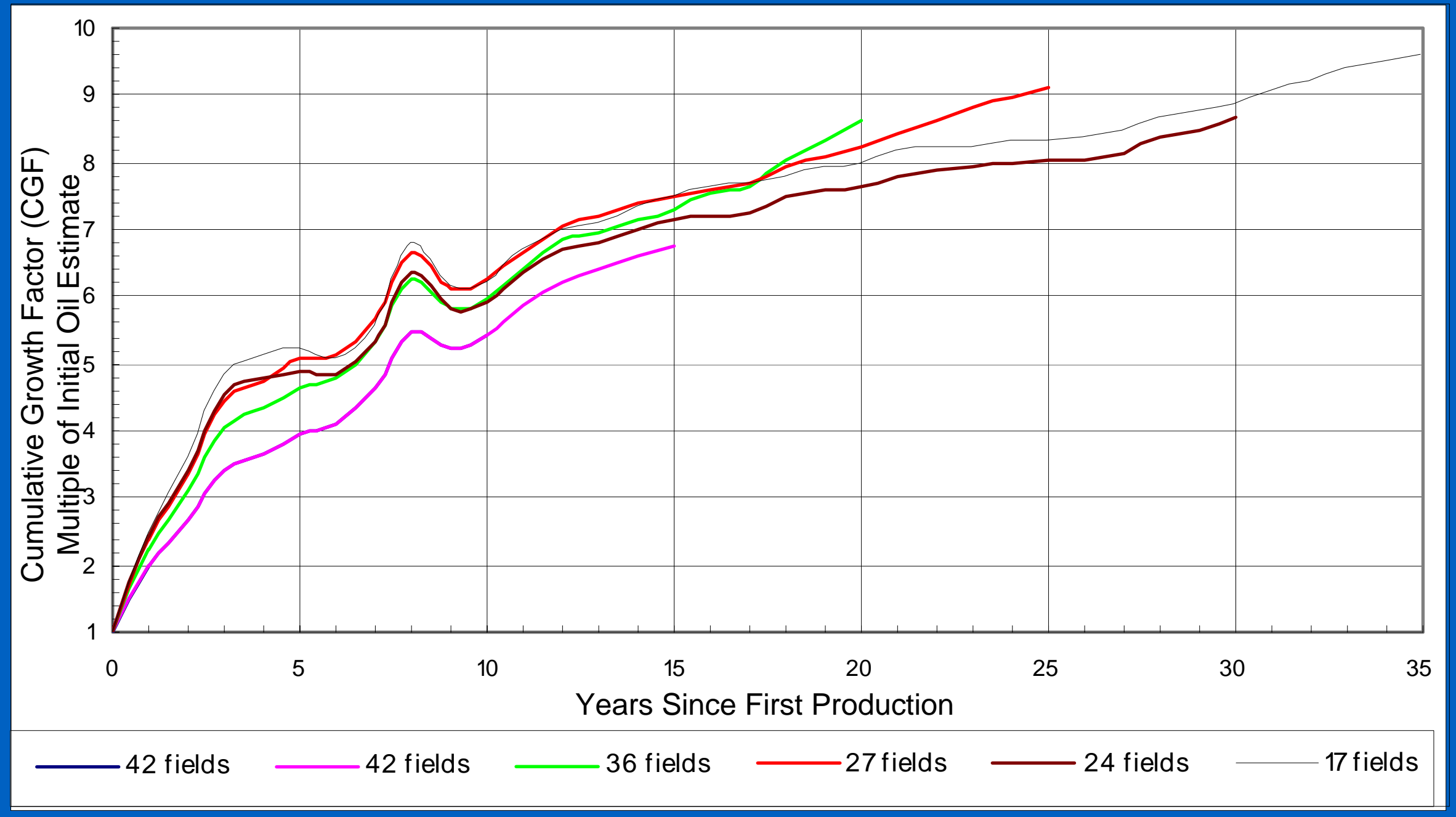

\section{ZUSGS}




\section{Cumulative Growth Factor for OIl Reserve growth at pool level}

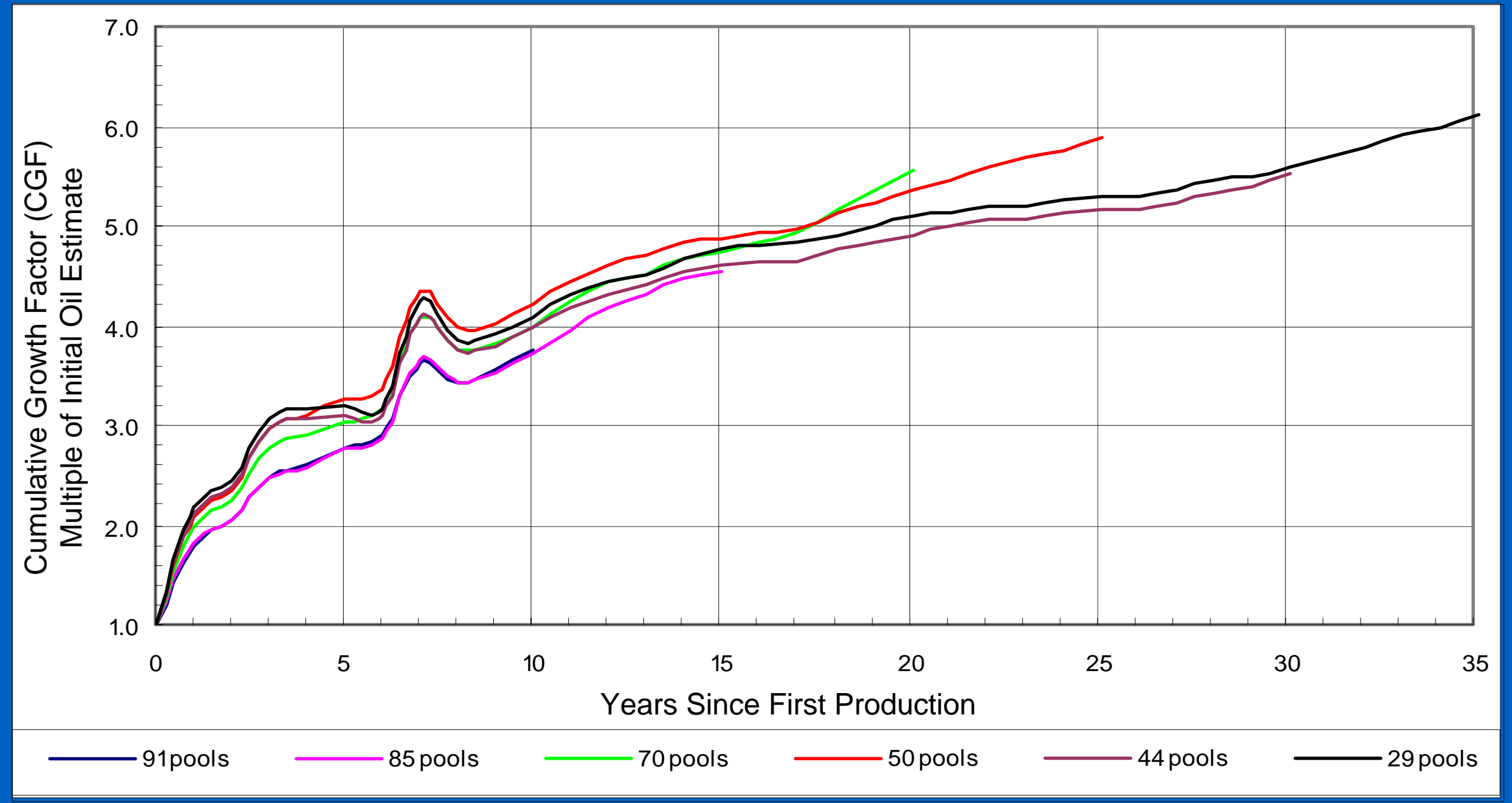

\section{¿USGS}




\section{Reserve Growth in Gas Pools}

* Of the 175 gas pools, 51 have adequate data for reserve growth study.

* Of the $\mathbf{5 1}$ pools, 45 are nonassociated gas pools and 6 are associated gas pools.

* Of the $\mathbf{4 5}$ nonassociated gas pools, only 12 have at least 25 years of reserve growth history. These 12 gas pools include the two largest:

-Hatton Milk River with 1.8 TCF gas reserves -Hatton Medicine Hat with 0.7 TCF gas reserve 话USGS 


\section{Cumulative Growth Factor for Gas Pools}

Based on Modjified Arrington and Group Growth methods

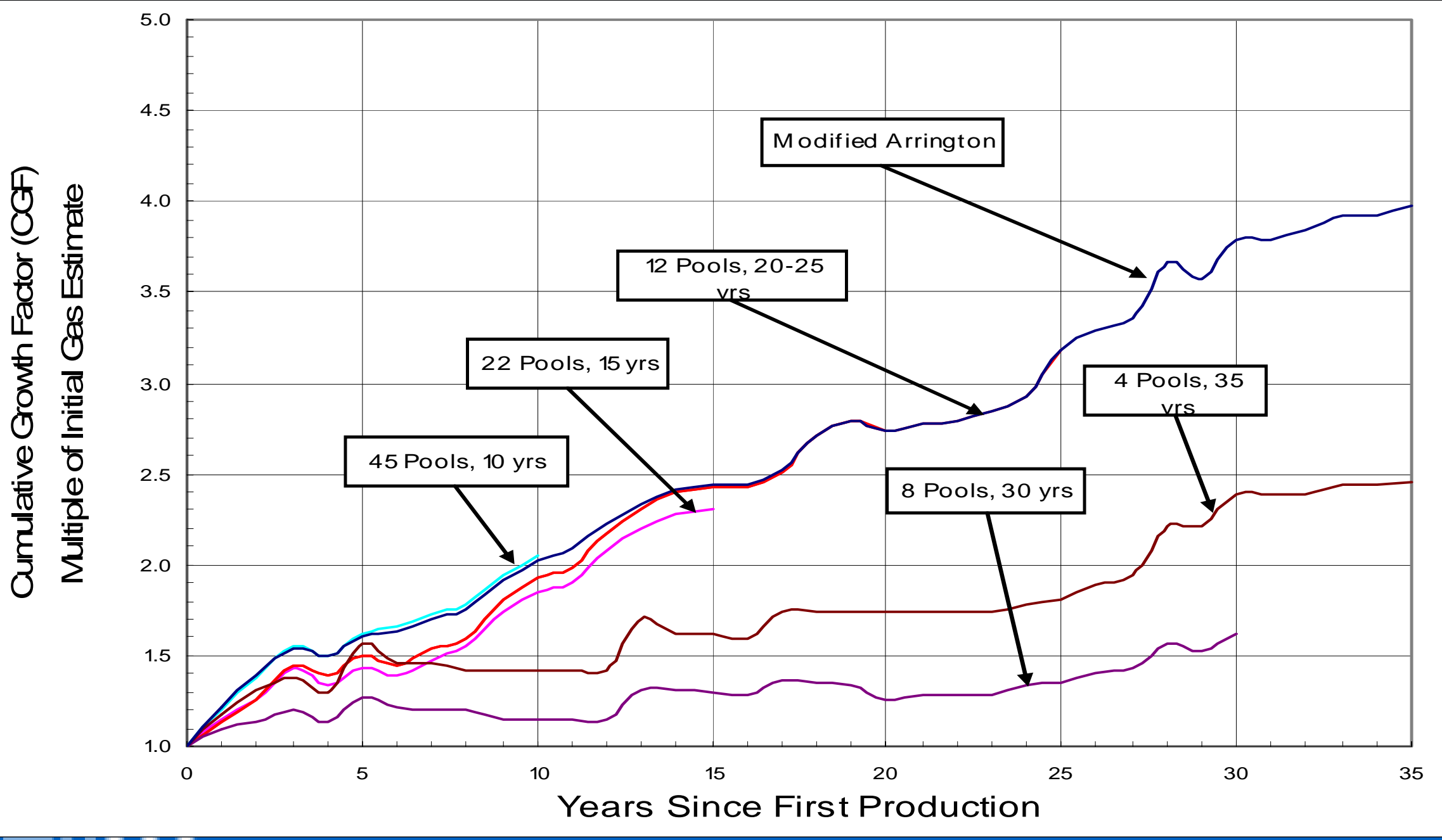




\section{Cumulative Growth Factor: Gas Pools}

12 nonassociated gas pools; for pools with reserves $\leq$ or $>500 \mathrm{BCF}$

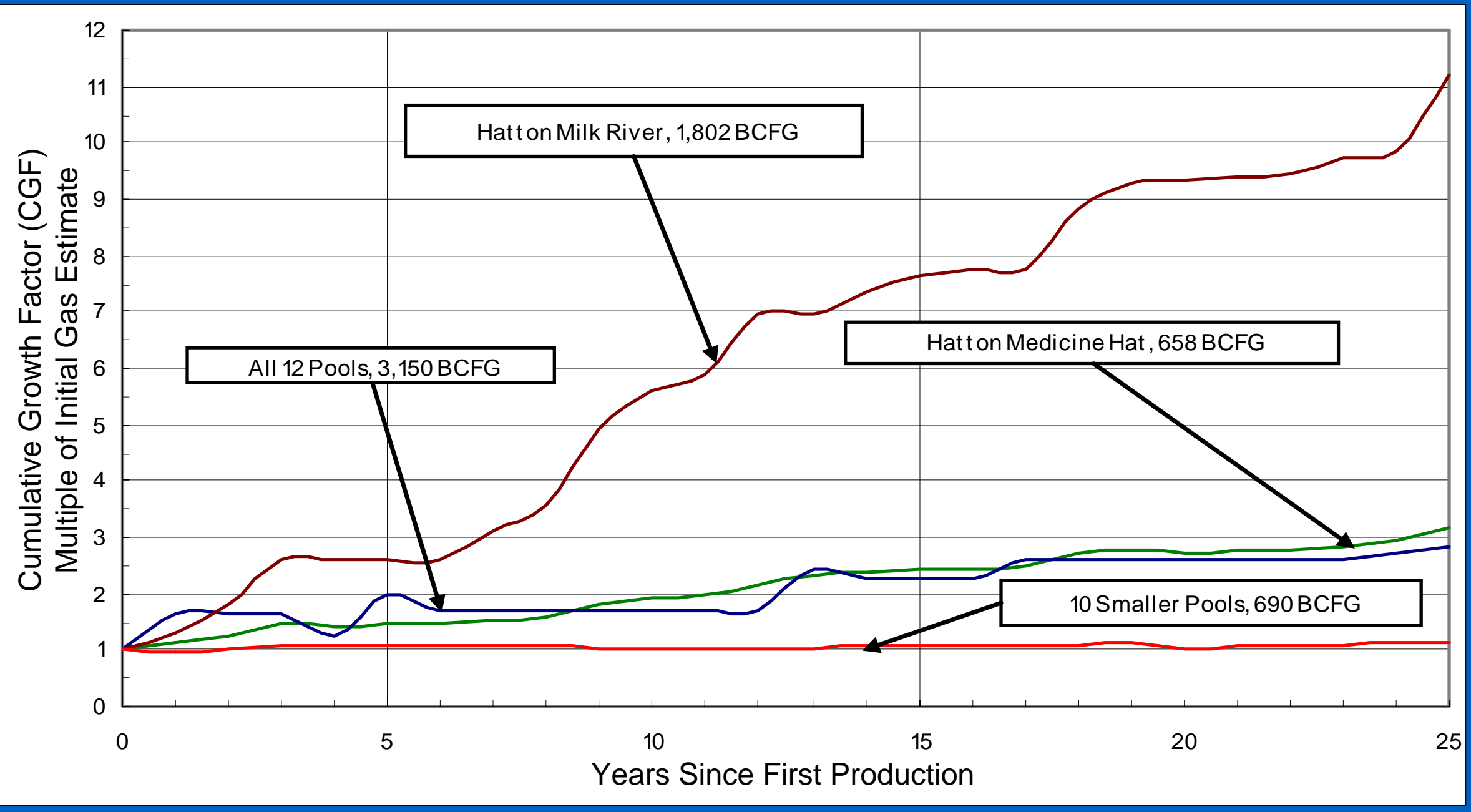

\section{₹USGS}




\section{Model Development}

* Two methods - Modified Arrington and Group Growth - were used to calculate cumulative growth factors (CGF).

* Oil CGF data from the two methods were plotted and regressed using the power function for the best fit to the transformed variables.

* Gas CGF data from the two methods were plotted and regressed using a linear function for the best fit.

\section{\#USGS}




\section{Cumulative Growth Factor: Oil Pools Data and Model Results}

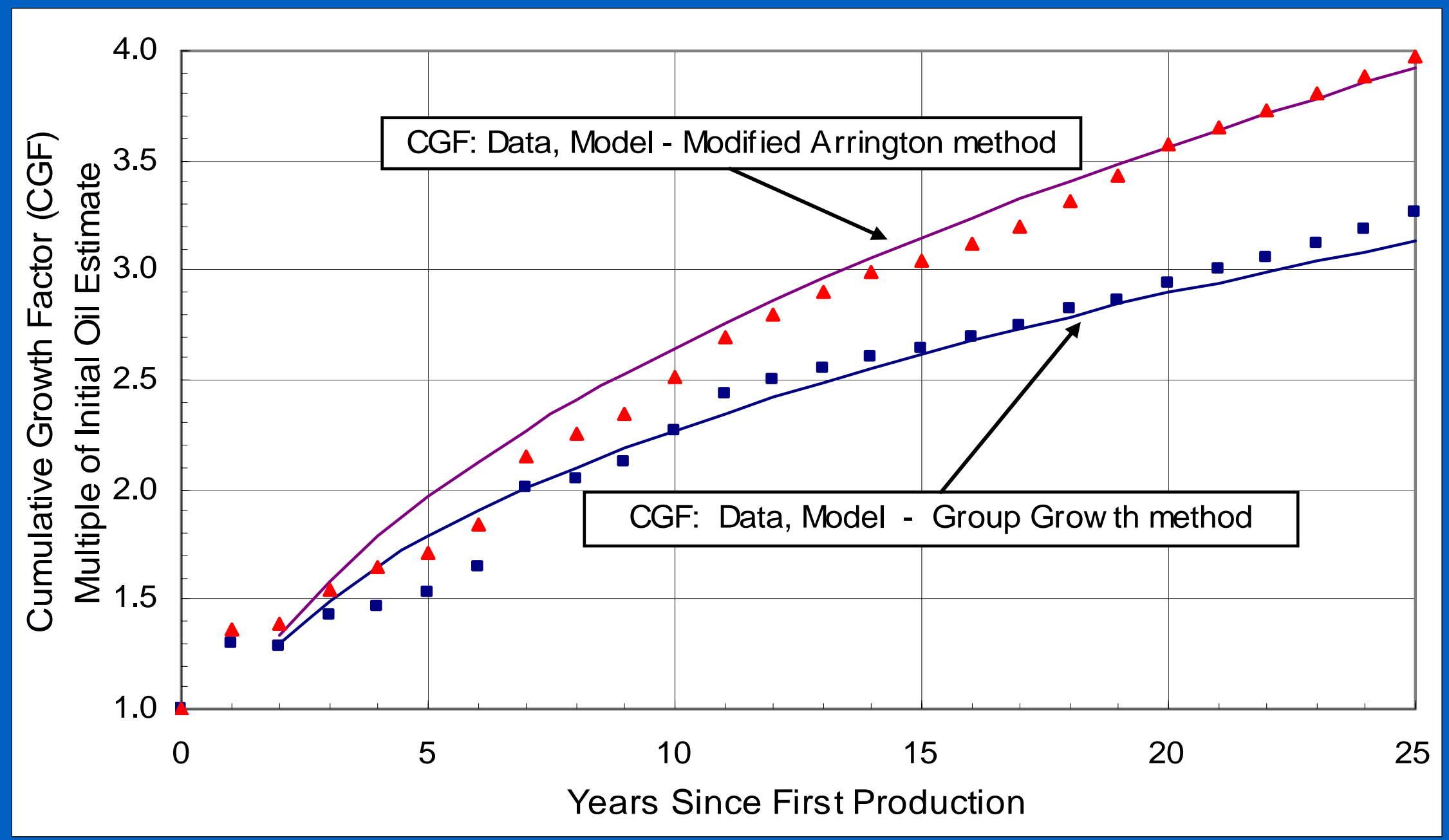

\section{‡USGS}




\section{Cumulative Growth Factor: Gas Pools Data and Model Results}

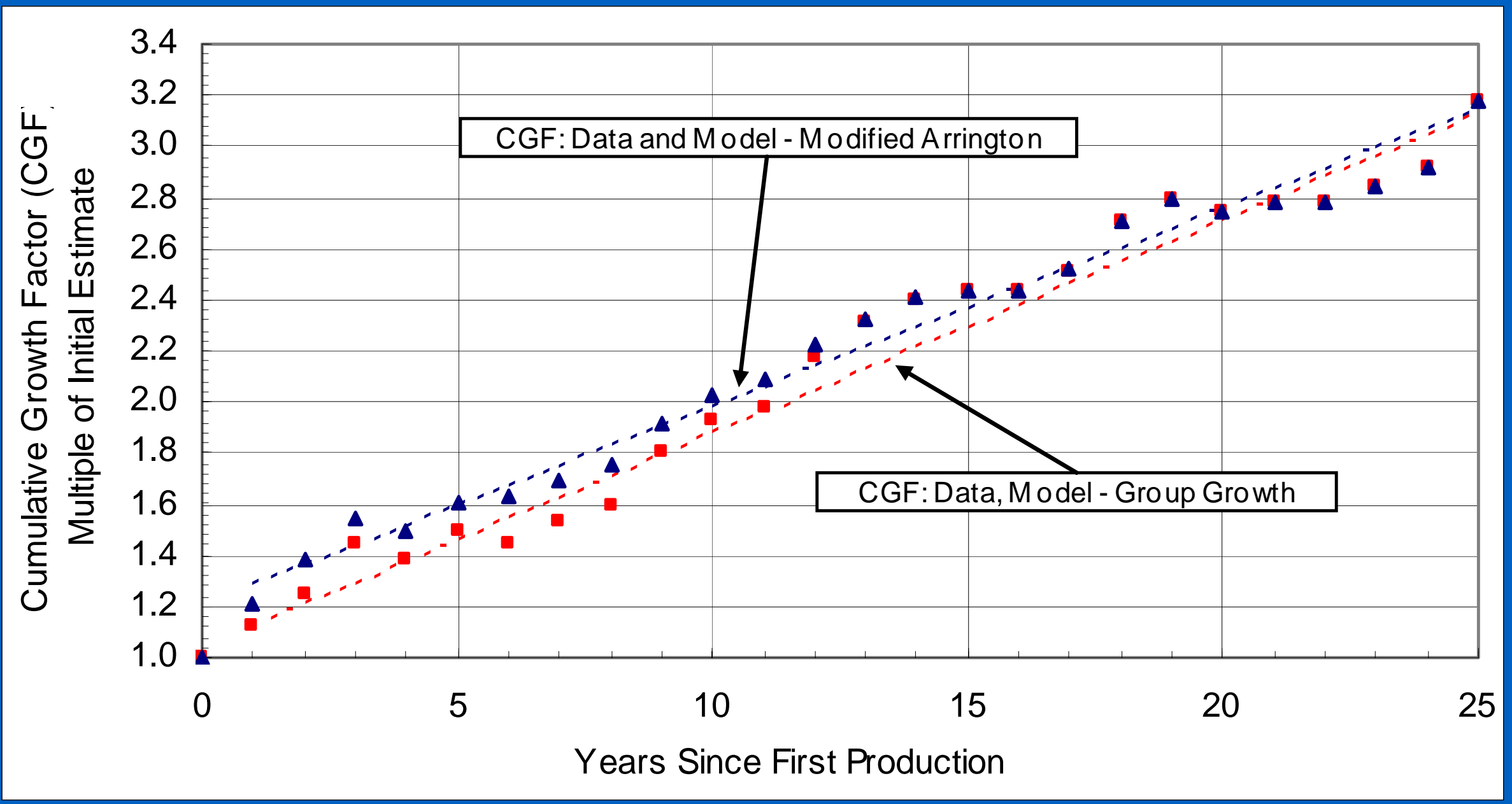

\section{₹USGS}




\section{Model Equations}

* Oil Pools: Power function used

$$
\begin{aligned}
& \text { CGF }=1.0191(\text { YSFP) } 0.3485 \ldots \text { Group Growth } \\
& \text { CGF }=0.9890(Y S F P) 0.4278 \ldots \text { Modified Arrington }
\end{aligned}
$$

* Gas Pools: Linear Function

CGF $=0.0835^{*} Y S F P+1.0375 .$. Group Growth CGF $=0.0775^{*}$ YSFP $+1.2033 .$. Modified Arrington

CGF: Cumulative growth factor YSFP: Years since first production 


\section{Discussion: Based on Model}

\section{Oil Pools:}

- Group Growth method: 3.13 - fold over 25 yr. $=4.7 \% / \mathrm{yr}$

- Modified Arrington method: 3.92-fold over $25 \mathrm{yr}=5.6 \% / \mathrm{yr}$

Annual pool growth for Saskatchewan pools is higher than for fields in U.K. $(2.3 \%)$, W. Siberia $(2.8 \%)$; similar to fields in Norway (4.6\%), Volga-Ural (5.3\%) and U.S. Gulf of Mexico offshore (5.5\%); and smaller than for fields in U.S. (6.3$7.2 \%)$.

Gas Pools:

-Both the methods give similar growth: 3.18 -fold $=4.7 \% / y$ -Annual reserve growth smaller than fields in conterminous U.S.

\section{\#USGS}




\section{Gas-in-place and Size of Developed Area as a Function of Time}

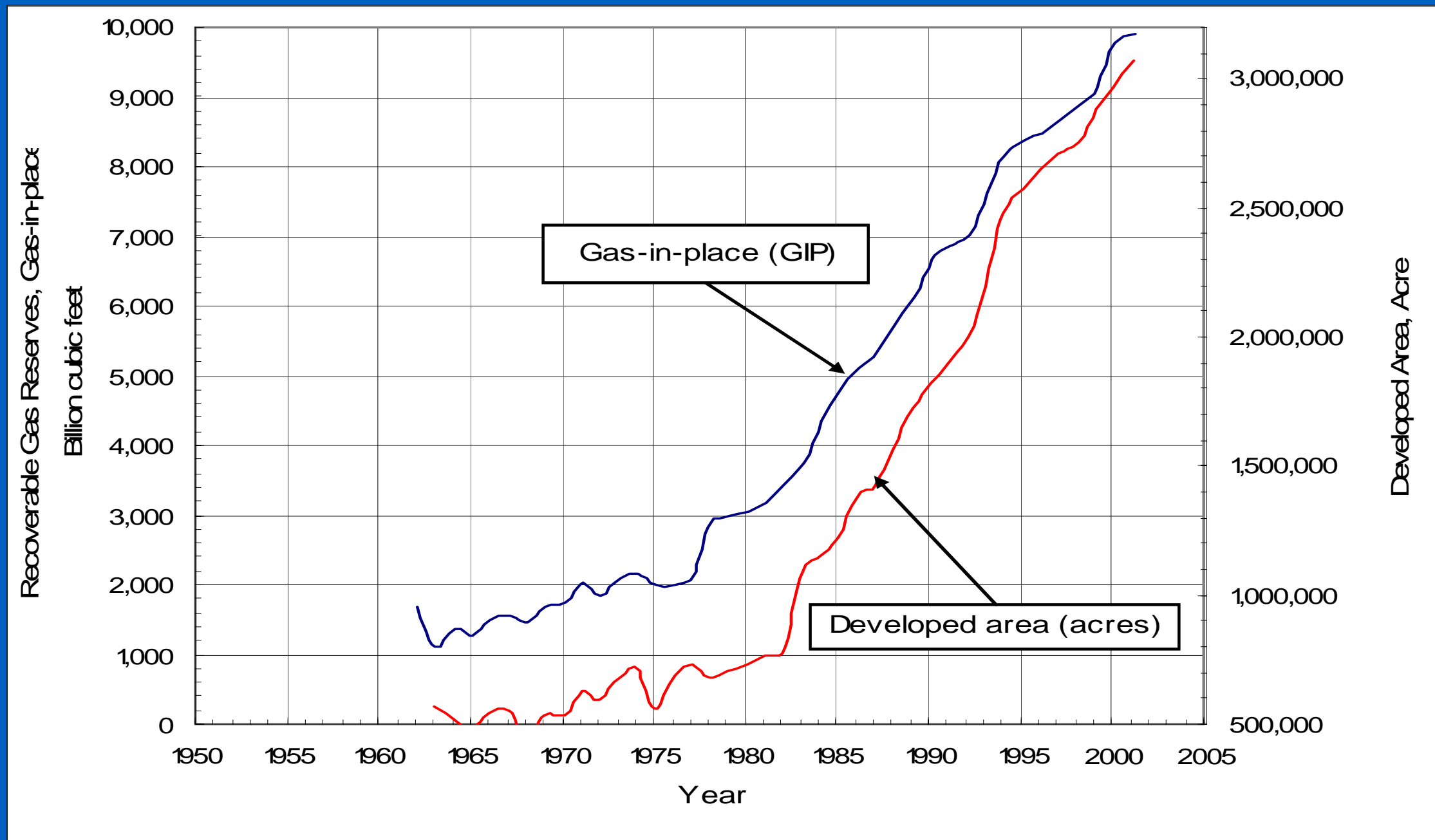




\section{Forecast of potential increases in Saskatchewan's oil and gas pool reserves, based on the modified Arrington method and the Group growth method}

Total hydrocarbon volumes (oil volumes are in millions of barrels and gas volumes in billions of cubic feet)

Year of Reserve Estimate/ Forecast

2001 2006 2011 2016
Oil Reserves, million barrels

Grown Oil Volume, million barrels Mod. Arrington Group Growth
Gas Reserves

Billion cubic feet
Grown Gas Volume

Billion cubic feet

Mod. Arrington Group Growth
$4,926.176$

$5,384.7$

$5,773.3$

$6,121.0$
$5,293.6$

$5,598.5$

$5,867.9$
6,864.635

$$
\begin{aligned}
& 7,782.5 \\
& 8,693.6 \\
& 9,604.7
\end{aligned}
$$

\section{ZUSES}




\section{Forecast of potential increases in Saskatchewan's oil and gas pool reserves, based on the Modified Arrington method and the Group Growth method}

Incremental hydrocarbon volumes (oil volumes are in millions of barrels and gas volumes in billions of cubic feet)

Year of Reserve

Forecast

Oil Volume,

Million barrels

Mod. Arrington Group Growth
Grown Gas Volume

Billion cubic feet

Mod. Arrington Group Growth
2006

2011

2016

\section{6}

847.1

1194.8
367.5

672.3

941.7
917.9

1829.0

2740.1
1003.7

2006.2

3008.7

\section{ZUSGS}




\section{Conclusions}

* Oil Pools:

- Overall growth in oil pools from models:

- Group Growth method: 3.13 - fold over $25 \mathrm{yr}=4.7 \% / y r$

- Modified Arrington method: 3.92-fold over 25 yr $=5.6 \% / y r$

- Reserve growth sensitivity to various parameters, based on CGF data and 25 years of growth:

- Heavy and light oil pools show similar growth (5.6\%/yr), and medium gravity oil pools show lower growth ( $3.7 \% / y r)$.

- Smaller pools (reserves <8 MM bbl) show lower growth $(2.3 \% / y r)$ compared to larger pools (reserves $>\mathbf{8} \mathbf{M M ~ b b l ) ~}(5.3 \% / \mathrm{yr})$.

- The four largest oil pools(reserves $>100 \mathrm{MM} \mathrm{bbl)} \mathrm{grew} \mathrm{by}$ $6.9 \% / y r$, and the remaining smaller pools by $4.9 \% / y r$.

- Growth at pool and field level for oil: Reserve growth at field level is about 50 percent higher than at the pool level, over a period of 25 years.

\section{Z USGS}




\section{Conclusions}

* Oil Pools (Continued):

- Average recovery factor for oil pools is about 15 percent.

- Difference in 5 - and 15 -year forecasts for a potential increase in oil reserves by the two methods ranges from 1.9 to 5.1 percent, respectively.

- Recovery factor is about $\mathbf{7 0}$ percent.

- Both methods gave similar growth 3.18 - fold = 4.7\%/yr.

- Difference in forecasts from the two models is less than 4 percent even at 15 years.

\section{ZUSGS}




\section{Reserve Growth Study for the Alberta Province}

* It is the province with the largest volumes of oil and gas accumulations in Canada. Alberta has some light but mostly heavy oil, and gas. Various estimates have been offered over the years. Recent estimate of Canada's reserves include 175 billion barrels of heavy oil from tar sand deposits.

* Data obtained from Alberta Energy and Utilities Board (EUB), Calgary.

- Earlier data (1955 -1977) are available on microfiche; incomplete or missing for some years.

- Remaining data (1978-1998) are in digital format.

- Recent data from 1999 to 2003 or 2004 will be obtained from EUB.

\section{\#USGS}




\section{Alberta's Oil and Gas Volumes}

(Source: Alberta Energy and Utilities Board, 1978-1998)

Year Oil-in-place Initial Oil Reserves billion bbl (Cum prod + remaining reserves) billion bbl

$1978 \quad 56.8$

$1998 \quad 85.4$
17.3

23.8
Gas-in-place

Trillion cubic feet

155.3

245.5
Initial Gas Reserves (Cum prod + remaining reserves)

Trillion cubic feet
101.5

156.0

\section{₹USGS}

